\title{
Interreligious Education at the Reconstructionist Rabbinical College: A View from the Jewish Edge
}

\author{
Nancy Fuchs Kreimer
}

\begin{abstract}
This chapter reports on the Reconstructionist Rabbinical College (RRC)'s bold experimentation in the field of inter religious education as integral to its mission. It chronicles how, with the support of the Henry Luce Foundation, over the last decade and a half, RRC has responded to developments in the American and Jewish environment with an-ever evolving approach to the training of clergy. The chapter details two signature programs, one to build solidarity between Jews and Muslims, the other to create a novel entry point for education in interreligious literacy and co-spiritual formation across multiple traditions.
\end{abstract}

\section{Introduction}

In 1941, Rabbi Mordecai M. Kaplan shocked the traditional Jewish world by publishing what he called "The New Haggadah." The founder of the Reconstructionist Movement heavily edited the traditional liturgy for the Passover Seder, making the story of the Exodus both more humanistic and more universal. Today there are thousands of versions of the Haggadah, but in the midst of World War II this was a radical move. Years later, the Reconstructionist Rabbinical College (RRC) continues the tradition of radical, forward thinking, evidenced by the early inclusion of GLBTQ rabbinical students, our ability to hold a range of views regarding Israel and Palestine, and our groundbreaking multifaith initiatives. In 2015, the Jewish press spotlighted — often critically-RRC's decision to accept rabbinical students with non-Jewish partners. We boast that "multifaith is in our DNA." Our leadership, both lay and professional, is proud of our work in this area. That said, our story is not a simple one. From where we sit, the work of seminary interreligious education is urgent, deeply meaningful, and, in that overused but perfectly apt word, complicated.

As Reconstructionists, we see ourselves living at the edge of the Jewish world, situated to grapple with some of the most difficult questions raised by a 
changing religious landscape, questions that are not limited to us or even to Jews. These issues already impact, or will in time, many who care about the flourishing of religious communities. In the last decade, thanks to the vision of the Luce Foundation, we at RRC have been able to experiment boldly as we consider what these changes mean for clergy training. In this paper I will review the institutional history of the RRC against the backdrop of developments in the Jewish and American scene.

The focus will be on the emergence and evolution of two signature projects, responding to two sets of questions, both related to religious difference. The first project involves combating the negative potential of difference- the way in which religious difference can be exploited to generate fear and hatred. Today, that concern manifests most saliently for us in the troubling rise of xenophobia, especially toward Muslim Americans. Our Muslim-Jewish Engagement program asks how we can empower our students to lead their communities toward more nuanced understanding and solidarity with Muslim Americans, even as issues between our communities become more fraught.

Our second project, Cultivating Character: Conversations Across Communities $(\mathrm{C}-4)$, responds to a different set of questions about difference. As the boundaries of our communities become more fluid, people define themselves less through solidarity with particular religions and more as individuals with complex, often multiple sources of identity. How will the nature of interreligious encounter change? How will people located in a given religious tradition continue to be rooted and nourished by that tradition? How will those traditions continue to flourish? Can a novel entry point for interreligious literacy also contribute to the spiritual formation of individuals? We are trying to develop a framework for people from different traditions to ground themselves more deeply, even as they open themselves more widely.

For both these projects, we have created courses for our own students and retreats for a wide spectrum of leaders and emerging leaders. The RRC has mined its institutional legacy in order to confront developing challenges. As we pause to reflect on these efforts, we readily admit that we still have more questions than answers. We welcome the opportunity to continually learn from others.

In the first half of the twentieth century, influenced by John Dewey and William James, Mordecai Kaplan created the Reconstructionist approach to Judaism, the first Jewish denomination founded on American soil. Kaplan 
understood Judaism as the multivocal, evolving, religious civilization of the Jewish people. Rather than being chosen by God, Jews, along with other people, seek meaning through their sacred narratives, rituals, and traditions. Judaism, rather than being a timeless set of truths, is the Jewish people's flawed human attempt to bring the ethical and the sacred into our daily lives. In the post-World War II era, Jews saw interfaith work as a way to secure our place in the civil religion of America. ${ }^{1}$ In the 196os, some Jews and Christians found common cause in the civil rights and anti-war movements, as reflected in the iconic photograph of A. J. Heschel marching alongside Martin Luther King, Jr. in Selma.

Since its founding in 1968, RRC has taught Judaism through the civilizational approach. Jews have always interacted and learned from the people among whom we have lived. Thus, our education always included learning from the history of our interactions with other peoples, from contemporary social science, and from the values of American democracy. Kaplan's phrase "peoplehood" captured something powerful for Jews in the 1940s, when he coined it. It still made sense in the 1970s, when the rate of intermarriage between Jews and non-Jews was under 20 percent (of the Jewish population) and many American Jews were only a second or third generation away from immigration. With the memory of the Nazi Holocaust still vivid, American Jews were virtually united in their support for worldwide Jewry.

As one of RRC's early graduates, I was inspired by the work of Christians who were reconstructing their theology, liturgy, and religious education in the light of the Holocaust. They believed that religion can be dangerously toxic as well as powerfully healing. They thought that those of us who were sustained by our spiritual traditions had a unique obligation to oppose the hate-mongers in our communities and become allies with those who have been harmed. I earned a PhD in Religion at Temple University with Christian scholars who were focused on helping Christianity and Christians "get it right" in relation to Jews and Judaism. The mission aligned well with the "peoplehood" focus of the Reconstructionist movement and its pragmatic orientation: theology made sense in the service of real-world issues of justice.

\section{3}

\section{The Eighties and Nineties}

When RRC moved from the inner city of Philadelphia to a suburban campus in 1982, the institution strove to continue its commitments to a wider world. Soon

1 For example, Will Herberg's Protestant, Catholic, Jew: An Essay in American Religious Sociology (Chicago: University of Chicago Press, 1983). 
after, the dean invited me to establish a Department of Religious Studies. The RRC became the first — and for many years the only—rabbinical school to require courses in other religious traditions as a prerequisite for ordination. The requirement was two full courses from among a rotating menu that included Christianity, Islam, Jewish-Christian Dialogue, Eastern Religions, and Religion and Science. My job was part time, and most of the courses were taught by adjuncts.

The Introduction to Christianity course, taught by Hal Taussig for over fifteen years, was required for all students. Taussig reported that in the beginning it would take half the semester for some students to relax their Jewish guard and begin to open themselves to the material. These students had clearly defined boundaries of the self as Jewish. And yet, conversations with the "other," as strange and confusing as they might be at the beginning, became a valued skill. The course prepared the Jewish students to work in a non-Jewish, mostly Christian world.

As the nineties waned and the promise of the Oslo Accords dissolved, both the Holocaust and the State of Israel, twin pillars of Jewish identity for decades, began to hold less power for the next generation. In my own work, I began wondering if Christian anti-Judaism continued to be the most serious problem needing attention at this time. Muslim Americans were barely on our radar. Throughout this period, we regularly engaged a scholar from Temple University's Religion Department to offer an academic course on the history and beliefs of Islam. We thought we were doing well.

It did not take long after September 11, 2001 to realize that our program in Islam needed a major overhaul. The interfaith world had "discovered" Muslims; I was invited to participate in panels with imams and Muslim public intellectuals. I soon realized that my own graduate school preparation was woefully inadequate. I knew very little about the Muslims I was encountering. Who were they? What was their history in this country? What were their concerns and hopes? I committed myself to figuring out how to train rabbis who could be responsible partners working in solidarity with Muslim Americans.

My own commitment to religious values in action shifted its focus to helping Jews "get it right" in relation to Muslims in America. I understood the work - educating our students to be allies in fighting Islamophobia — as a tribute to my Christian mentors. It was also deeply aligned with my Reconstructionist and progressive Jewish concerns for an inclusive American religious 
landscape. It was not clear then how challenging this work would continue to be in the wider Jewish world.

Soon after 9/11, we invited a Pakistani American doctoral student from the University of Pennsylvania to teach a contemporary version of the "Introduction to Islam" course. We added a requirement to visit a mosque to witness a service. (A parallel assignment had been a standard part of the Christianity course for decades.) Students appreciated getting to know their Muslim teacher. They loved that he was, like them, a graduate student who was able to share his personal experience of faith and practice. The upgrade to our basic course in Islam still left much to be desired, however. Students found it difficult to connect with a mosque and found the service confusing and uncomfortable, especially for the women in the class. For some, it reinforced their sense of Islam as foreign.

I needed to find a better way to take students into the world of Muslim Americans, and I knew that the best guides would their peers who were Muslim. We began a partnership with the Middle East Center at the University of Pennsylvania. The Center agreed to recruit and provide a stipend for Muslim graduate students to participate in a community-based learning component. As the course developed, Jewish and Muslim students were paired and expected to schedule three additional sessions with each other. They engaged in Qur'an and Torah study, visited a service at a mosque, and planned and executed a teaching session about Islam and Muslims at a Jewish venue.

Most students were curious, eager, and openhearted. Some of the younger students had college friends who were Muslim, but few, if any, had ever been inside a mosque. Paired with a Muslim peer, the experiences were far more positive than when they had gone alone. The students and their Muslim peers created successful programs for Hebrew schools, for Jewish nursing homes, and for synagogue Shabbat lunch-and-learns. Audiences were grateful for the simple opportunity to meet with a Muslim (a Penn graduate student!) and be able to ask "everything they always wanted to know about Islam." Muslim students were willing to help. "Get to know your neighbor's faith" was both forward-looking and appropriate.

Since none of our sister seminaries on the East Coast provided any education in Islam at the time, RRC began organizing retreats with emerging Muslim and Jewish leaders. While most programs convene either "Abrahamic" or multifaith conversations, we believed that the intensity of history and feeling - both negative and positive- between Jews and Muslims merited a particular conversation. More than once we heard from students, "How could I have thought of becoming a Muslim/Jewish leader without this experience?" 
A total of sixty-four Muslim and Jewish emerging leaders participated in one of our four-day retreats and follow-up programming. Eight participants have returned as "alumni facilitators" to help plan and present later retreats, greatly enhancing the program and their own leadership skills. The cohort is equally split between Jews (rabbinical students from across the denominational spectrum) and Muslims (graduate students, chaplains, journalists, and activists from diverse backgrounds). Retreat alumni continue to build on the skills, knowledge and, most important, the relationships they forge in our program. They continue to network with each other by phone and social media and, in some cases, have established ongoing professional collaboration.

During this decade, we also began tracking changing Jewish demographics as well as emerging understandings of identity. When Shaul Magid and others first began drawing attention to post-ethnic trends in American religious life, ${ }^{2}$ Steven M. Cohen and Jack Wertheimer issued a strong response: "Whereas [Magid] applauds the shift to a porous, self-constructed, and voluntary ethnicity ... [w] take wary cognizance of post ethnicity and urge American Jews to contend with it, rather than surrender."3 Rather than "contending," as Cohen and Wertheimer suggest, we have moved from hand-wringing to curiosity and active engagement. Many liberal denominations now have non-Jews in their pews. The Reconstructionist movement has been a leader in recognizing these fellow travelers as members of our communities.

When our students held clearly-defined boundaries of themselves as Jewish, conversations with the "other" were of course challenging, but they prepared them to work in a world of diversity. Many of our students now live that diversity daily in the communities they serve, and in their families and homes. The realization that the "other" is not so "other" is particularly significant when working with Jewish youth, who often have hybrid religious identities.

The 2013 Pew Survey confirmed what we knew anecdotally: the intermarriage rate had climbed to over 50 percent (for non-Orthodox Jews over 70 percent). ${ }^{4}$ When we first conceptualized the challenge of including multifaith learning in our curriculum, we thought we would have to compete for scarce resources, and confessed in our grant proposals: "Unfortunately, many of our

2 See David A. Hollinger, Postethnic America: Beyond Multiculturalism (New York: Basic Books, 1995); Shaul Magid, American Post-Judaism: Identity and Renewal in a Postethnic Society (Bloomington, IN: Indiana University Press, 2013).

3 Steven M. Cohen and Jack Wertheimer, "What is So Great about Post-Ethnic Judaism?" Sh'ma: A Journal of Jewish Ideas, March 1, 2011, accessed October 17, 2019, http://shma.com/2011/o3/ what-is-so-great-about-post-ethnic-judaism/.

4 See Pew Research Center, "A Portrait of Jewish Americans," accessed October 17, 2019, http:// www.pewforum.org/2013/10/01/jewish-american-beliefs-attitudes-culture-survey/. 
students, attracted by our expansive vision, are in need of more immersion in the languages and rhythms of Jewish life. We are constantly struggling to find time in the curriculum to address those gaps alongside our robust multifaith offerings."

As the RRC student community became more diverse, our students' grounding in Jewish traditions was increasingly in need of enrichment. Many faculty members wanted rabbinical training to immerse our students in Judaism so that they would become "vessels of Torah," living exemplars of an (albeit contemporary) religious tradition. They would then be able to lead their communities to a more robust embrace of Jewish life. In fact, those of us who were advocating for multifaith and social justice education did not disagree!

Our students themselves recognized that there could be a conflict between the various goals we have for them. In the Leadership Skills for Pluralism course we responded to students' stated desire to place a heavy emphasis on multifaith social justice collaboration. One student wrote, "Now I am wondering how much I should be encouraging my future congregation to engage in this kind of activity, and how much I should be teaching them how to pray, study, and live in uniquely Jewish ways."

In recent years, we at RRC have been rethinking our approach to MuslimJewish engagement and, at the same time, we have been developing the Cultivating Character project as a new entry point to interreligious learning.

The Gaza invasions in the summer of 2012 and 2014 heightened tensions between Jews and Muslims in this country. During the run-up to the 2016 presidential election, the rise of ISIs, multiple terrorist attacks in Europe, and the divisive rhetoric unleashed by Republican political candidates have made the situation of Muslims in the United States much more vulnerable. At the same time, the rapid growth of the Boycott, Divestment, Sanctions (BDS) movement on campus signaled a new development among students at RRC. We began seeing a wider range of views than before, including non-Zionist and antiZionist students in our rabbinical program. The issue of Israel/Palestine has become increasingly divisive both within the Jewish community and between Muslims and Jews.

In 2015 I became convinced that our Muslims in America course was no longer adequate for the new, increasingly challenging times in which we live. Students were finding it more difficult to schedule Jewish venues to host the Muslim program. In one case, a student who worked for a Hillel was unable to 
fulfill the assignment where he worked because his supervisor was unwilling to sponsor the Muslim guest speaker. This was at the very same campus where, four years earlier, one of our students had led a successful program with his Muslim peer. Other venues refused to host a Muslim student who was involved with the Council for American Islamic Relations (CAIR), and many Jewish institutions have declared CAIR to be "off-limits."

In sharp contrast to the seemingly increasing acceptance of Christians and Christianity, we have noted an increased wariness, even fear (although less common) with regard to Muslims. The current climate of Islamophobia in this country impacts even progressive communities, and we have noted how Islamophobia and Israel/Palestine issues have become linked in the view of both Jews and Muslims.

The RRC has also found it more difficult to recruit Muslim graduate students. This might be attributable, in part, to "ambassador fatigue." Emerging Muslim leaders are heavily in demand to speak and represent their communities, and many are finding these new social duties a distraction from their own scholarship and professional work. It may also reflect less willingness to volunteer to educate Jewish communities. A Muslim colleague helped me understand this problem more deeply: "Many non-Muslim spaces feel less than safe. We are called in to apologize for worldwide Muslim terrorism. It threatens our dignity as human beings."

As I consulted with Muslim colleagues, I realize that to do justice to the issues in our society, we need to further refine our program. The original design presumed that building a relationship with a Muslim and then modeling that relationship in a Jewish venue would be good enough, and in many ways, it was adequate for the time. In the years after $9 / 11$, we capitalized on the openhearted curiosity of American Jews who were willing to confront their own ignorance on the subject of Islam and Muslims.

Today, as politicians and pundits ratchet up levels of Islamophobia in our society and in the Jewish community, RRC's rabbinical students need more thorough and sophisticated preparation. The problem is no longer simply lack of knowledge or personal experience with Islam and Muslims. Students must develop a conceptual framework in response to concerns they will hear voiced and — let it be said — concerns in their own minds. They need a sophisticated analysis of Islamophobia in America and in the Jewish community. They need to engage the charge of "the Islamic roots of IsIs" with more than simplistic rhetoric that "Islam is a religion of peace." They need to get deeper into the complexities of the issues confronting global Islam and Muslim Americans today. To truly understand what is happening now, it is not the Qur'an but rather the last two hundred years of history that will help most. We need to teach 
students how to recognize the flashpoints of conflict between communities and prepare for encounters beyond attending a Muslim lecture.

At our Muslim-Jewish leadership retreats the issue of Israel/Palestine had become increasingly fraught. We had dealt with the "elephant in the room" in different ways-declaring the topic off-limits, arranging highly structured dialogues, or just dancing around the edges. Our failure to successfully address the topic impeded our progress on other fronts. While Jews and Muslims are natural allies in many ways, we also found ourselves countering Islamophobia and antisemitism in our own communities, with Israel/Palestine at the core.

While it is true that this issue often divides Jews and Muslims, it is also true that neither of our communities is monolithic in its views. The official communal agendas are hotly contested and many of our emerging leaders are among those doing the contesting. At RRC, we had been working to manage a wide range of views around Zionism, including the largest cohort on the far left of any rabbinical school. We knew that deep fissures existed in the Muslim community as well.

Since we were polarized, both between and within our respective communities, we believed this was the right moment to jump in feet first. For our fifth retreat in August 2016, we selected sixteen alumni from previous retreats and carefully designed a process to build on the trust we had established to take this critical conversation to the next level. Unlike the four prior retreats, this event had a singular focus, i.e., the ways in which the Israeli/Palestinian conflict divides our Jewish and Muslim communities. We wanted to explore how this issue impacts our communities' relationship with each other and the larger American (Christian and secular) world, including its impact on Islamophobia and antisemitism. We wanted to learn how we could use our relationships with one another to work toward less polarization and more mutual understanding, so that we could better train leaders in our own communities. Our experience at that retreat served to confirm and deepen an insight we had the previous year-that interfaith encounter works best when focused less on issues that divide us and more on the spiritual and ethical practices that sustain us.

In 2014, at the fourth retreat, we learned something of value going forward. This event was "women only," at the request of some of the Muslim participants from past retreats. With one less difference to negotiate, we hoped to see the rapid bonding that often happens in same-gender groups. In fact, something quite different occurred. Perhaps because of the more intimate, vulnerable female space, our differences - especially around Israel and Palestine, but also class and race-emerged more strongly than in the past. We engaged in our usual modalities of connection: text study, structured conversations, and 
the like, but tensions roiled under the surface and, occasionally, above it as well. One morning, one of the Muslim participants offered to share her spiritual practice of $d h i k r$ (a form of Sufi chanting) and invited others to join if they felt comfortable.

One participant noted that "It was amazing to be 'allowed in'-welcomed in, actually, to Sufi Muslim practice as a Jew." She reflected how so much of interfaith work is about dialogue, but faith is so much more than what one talks about. "This small experience of sharing a practice was a glimpse into another model of interfaith connection that we were just beginning to explore. Sharing spiritual practices can establish a level of connection and a different kind of trust. In that case, it allowed us to move back into the more difficult places of interfaith dialogue and disagreement."

Which leads us into a discussion of RRC's second project, Cultivating Character: Conversations Across Communities (C-4). In 2013 our faculty completed a thorough reimagining of the rabbinic curriculum. After three years of exploration and negotiation between competing demands, the multifaith requirement remained two full courses, this time including one on Islam. The requirement continues to be among the most robust among seminaries. At the same time, our students' mandatory period of study in Israel, immersed in a fully Jewish environment, has been changing. Many students go for less time than they once did, and some have been clear that their primary interest in the Israel study period is in Palestinian solidarity work.

In response to the issues we began tracking, as discussed above, we have also recalibrated the goals of RRC's multifaith courses. We still aim to equip students with the knowledge and skills to be interfaith leaders and to combat xenophobia, particularly in the Jewish community. At the same time, we want our students to use the encounter with people of other faiths as a resource for their own ongoing spiritual/ethical formation, along with deepening their own Jewish beliefs and practices.

Encouraged by the Luce Foundation to explore new pedagogies and models for interreligious learning and encounter, we proposed Cultivating Character: Conversations Across Communities. The program began four years ago as an idea for a series of retreats and is now a course in the RRC curriculum. It quickly became a model for interfaith encounters, generating enthusiasm and interest in the wider world. Our "brain trust" worked to adapt the innovative model to the training of campus professionals.

The C-4 program grew out of my own spiritual journey. When I began a serious practice of Mussar (a traditional Jewish discipline of character cultivation) my Jewish formation really flourished. As I practiced in a program that met weekly with a rabbi for over a decade, I also wondered about the spiritual and 
ethical disciplines of other religious traditions. The best interfaith encounters involve people whose hearts are a mile wide and whose spiritual grounding is a mile deep. Rabbi Zalman Schachter-Shalomi (a former teacher of mine and the founder the Jewish Renewal movement) was a model of a completely, authentically Jewish person while learning with Catholics and Sufis, among others.

The $\mathrm{C}-4$ is a program for religious leaders that focuses on character. Conversations between Jews, Humanists, Christians, Buddhists, and Muslims are dialogues across differences-different theological assumptions, different vocabularies, different practices. With the common concern of character cultivation, we meet one another in a vulnerable, openhearted place and find commonality. This experience can nurture us as we engage in more difficult conversations. In this process, each tradition would, we argued, maintain its own integrity. "The goal will be mutual enrichment—cross-fertilization and inspiration - not an effort to achieve 'synthesis,' a common language or fusion of practices." This is a new entry point into interfaith literacy. After close to three years of work, we feel we are "on to something" that is both more complicated and more promising than we initially thought.

At C-4 retreats participants speak about their own character challenges and the practices they find in their traditions. We teach one another and experience a variety of practices in a variety of modalities. By teaching, participants learn more about the value of their own practice; through learning, they experience another faith and reflect on the growth of their own soul. People find growth and connection in unanticipated ways.

Before the retreat begins, participants write about and share their own character challenges with one another. When beginning from this place of vulnerability, even veterans of multifaith "dialogue" quickly realize that the process elicits surprising honesty and depth. Over time, each participant teaches about a spiritual practice (e.g., bowing in a Muslim prayer service, Buddhist walking meditation, Jewish text study), share their own story of why the practice is meaningful to them, and invite others to participate in the practice if they are comfortable doing so. Reflections follow. What does it mean for a Jew to experience the embodied nature of Muslim prayer, or for a Buddhist to learn how community plays a part in the spiritual practice of a Roman Catholic? Shared aspirations and softening edges open a gateway into another faith that transcends theology or politics.

Recently, the religious world has begun to recognize the growing population of so-called "nones," the "spiritual but not religious" folks who are beginning

5 Robert D. Putnam and David E. Campbell, American Grace: How Religion Divides and Unites Us (New York: Simon \& Schuster, 2010). 
to demand a seat at the interfaith table. The old-style interfaith dialogue settings struggle to accommodate those who identify as "humanists," "secular," "trans-spiritual," etc. Our informants tell us that on college campuses where such an option exists, the secular humanist advisor does a brisk business, while the "religious advisors council" struggles to expand to include this option.

As Reconstructionists, we are well positioned to understand and respond to this phenomenon, since our own theological roots as a movement grew from, among other sources, the secular humanism of Felix Adler, one of Kaplan's teachers. Many Reconstructionists do not define themselves through religious belief. In developing the Cultivating Character program we chose to use the word "communities" and leave open the space for those voices. The very frame of character cultivation invites this addition and we are eager to see how it will enrich the conversation as more people locate themselves outside traditional religious groups.

When we offered a C-4 course at RRC for our students, we designed it to explicitly ground the students in their own formation as Jews. For ten days students take on a Jewish observance that they do not currently practice, such as saying blessings after meals, kissing the mezuzot on passing a doorway, or going to mikveh. They take on such practices with the intention of cultivating a particular character trait. Only then are they introduced to Christian and Muslim practices.

Imagine! Over a semester, rabbinical students participate in lectio divina, Ignatius' Examen and Christian Intercessory Prayer, dhikr, five-times-daily statutory prayer, and the Sufi evening accounting of the soul. They are also required to write a lesson plan of how they would teach a Jewish spiritual practice to an interfaith group, in which they explain the origins and meaning of the practice, their own relationship to it, and how they would engage the group in experiencing it. Each student prepares a protocol and conducts an interview with someone from another religious tradition, investigating their spiritual practices in relation to character cultivation. For the final assignment, students design an interfaith program involving $\mathrm{C}-4$ sharing for a specific setting in which they work or might someday work.

In the session on lectio divina with Francesca Nuzzolese of Palmer Seminary, students listened to a short piece of New Testament text three different times, each time letting the words enter them with a slightly different prompt, all more emotional than intellectual. They heard a text that was foreign, theologically provocative, and, for some, a negative trigger. They were instructed not to argue with it, or attempt to deconstruct it historically or linguistically. They engaged in the practice as practice, and they experienced what this traditional Christian approach to encountering text might teach them about themselves and their own practices of studying sacred text. A rich conversation followed. 
At a final session with our Muslim and Christian teachers, students turned to these religious guides as resources to help them think through their own issues. Many wanted to explore theology: Does what you do grow out of your faith in God? Does it strengthen it? Are you ever conflicted when a practice feels compelling but is imbedded in a theology that is problematic for you? How do you make use of what you learn from other traditions? Does it ever feel transgressive? How does "holy envy" work best in your life?

We have many questions about this methodology. For those such as the leaders in our retreats or our students, do we see an impact on participants' own spiritual practice? On their feeling rooted in their own tradition? On their understanding of and empathy toward the "other?" We have anecdotal evidence but want to know more. How might this pedagogy impact people with more fluid religious identities or less grounding in a particular tradition? Is it a good entry point for building conversations across differences? How might this pedagogy impact the range of religious professionals on college campuses?

We see our work on Cultivating Character as just beginning. We sit at the edge of the Jewish community, yet our issues are rapidly impacting others as well. Conversations with colleagues from many traditions-from liberal Protestants to Korean Buddhists-have taught us that these concerns are not only for Jews. As for Muslim-Jewish engagement, RRC's commitment to work at the edge of Muslim-Jewish relations continues unabated, as does our belief that we can only do this work in conversation with Muslims willing to go to the edge with us. We look forward to more opportunities to learn.

Postscript

In a well-known cartoon someone asks a fish, "How's the water?" The fish responds, "What's water?" Interfaith dialogue and understanding have become the water in which many of us swim. Indeed, the boundaries that once demarcated our tribes are blurring. In the Reconstructionist movement, multifaith is fast becoming our natural home. Ironically, Reconstructionists, known for articulating Jewishness as "peoplehood," are now at the forefront of a paradigm shift that is causing us to question that very idea.

Today, my own family is part of the great experiment in multifaith engagement. My two siblings and my two daughters are married to non-Jews. Our Thanksgiving table includes a Korean American, a practicing Roman Catholic, a "recovering" Catholic, and a secular Arab Muslim. Political and religious discussions at our family dinner sometimes require all the skills I have sought to hone in a lifetime of dialogue work. 
As a religious person, what is at stake for me is how I show up for the challenges of my life with humility and compassion, and how I may contribute. As an educator and a grandmother, what is at stake is the future. How will my students teach Jewish tradition so that it continues to yield blessings for those who engage in its practices? And how will Judaism, alongside other faith communities, contribute to healing our society, our country, and our planet?

\section{Bibliography}

Cohen Steven M., and Jack Wertheimer. "What is So Great about Post-Ethnic Judaism?" Sh'ma: A Journal of Jewish Ideas. March 1, 2011. Accessed October 17, 2019. http:// shma.com/2011/03/what-is-so-great-about-post-ethnic-judaism/.

Herberg, Will. Protestant, Catholic, Jew: An Essay in American Religious Sociology. Chicago: University of Chicago Press, 1983.

Hollinger, David A. Postethnic America: Beyond Multiculturalism. New York: Basic Books, 1995).

Magid, Shaul. American Post-Judaism: Identity and Renewal in a Postethnic Society. Bloomington, IN: Indiana University Press, 2013.

Pew Research Center. "A Portrait of Jewish Americans." Accessed October 17, 2019. http://www.pewforum.org/2013/10/o1/jewish-american-beliefs-attitudes-culturesurvey/.

Putnam, Robert D., and David E. Campbell. American Grace: How Religion Divides and Unites Us. New York: Simon \& Schuster, 2010. 